NBER WORKING PAPER SERIES

\title{
UNEMPLOYMENT INSURANCE \\ TAX BURDENS AND BENEFITS: \\ FUNDING FAMILY LEAVE AND REFORMING THE PAYROLL TAX
}

\author{
Patricia M. Anderson \\ Bruce D. Meyer \\ Working Paper 10043 \\ http://www.nber.org/papers/w10043
NATIONAL BUREAU OF ECONOMIC RESEARCH
1050 Massachusetts Avenue
Cambridge, MA 02138
October 2003

Work on this project was partially funded by a grant from the Employment Policies Institute. We thank Dick Toikka and participants at the June 2001 "America's Workforce Network Research Conference" in Washington, DC for useful comments. The views expressed herein are those of the authors and not necessarily those of the National Bureau of Economic Research.

(C2003 by Patricia M. Anderson and Bruce D. Meyer. All rights reserved. Short sections of text, not to exceed two paragraphs, may be quoted without explicit permission provided that full credit, including (C) notice, is given to the source. 
Unemployment Insurance Tax Burdens and Benefits:

Funding Family Leave and Reforming the Payroll Tax

Patricia M. Anderson and Bruce D. Meyer

NBER Working Paper No. 10043

October 2003

JEL No. H2, J6

\begin{abstract}
We examine the distributional consequences of the UI payroll tax using representative individual microdata. We calculate taxes paid by individual wage and individual and household income deciles, incorporating the effects of multiple job holding and turnover. This tax distribution is compared with the distribution of UI benefits and benefits net of taxes, as well as to the burdens imposed by the federal income tax. We conclude that the UI payroll tax is indeed quite regressive. Within the context of the regular UI program, this regressivity is offset by the progressive nature of benefits, leaving the net benefit distribution progressive. We simulate a revenue-neutral increase to the OASDI level of the taxable wage base. The share of total UI taxes paid becomes fairly equal, and net benefits become positive across more deciles. Finally, we examine the effect of providing family leave within the UI system as recently proposed. We find that the share of such benefits going to relatively high-income groups is likely to be much larger than is the case for regular UI benefits.
\end{abstract}

\author{
Patricia M. Anderson \\ Department of Economics \\ Dartmouth College \\ 6106 Rockefeller \\ Hanover, NH 03755-3514 \\ and NBER \\ patty.anderson@dartmouth.edu \\ Bruce D. Meyer \\ Department of Economics \\ Northwestern University \\ 2001 Sheridan Road \\ Evanston, IL 60208 \\ and NBER \\ bmeyer@northwestern.edu
}




\section{Introduction}

The Unemployment Insurance (UI) system was created by the Social Security Act of 1935. Originally, both UI and Old-age, Survivors, and Disability insurance (OASDI) were financed by a tax on the first $\$ 3,000$ in wages. In 1940 , this was roughly equal to average earnings. While the tax base for OASDI has risen over time, reaching $\$ 87,000$ in 2003 , the federal tax base for unemployment insurance remains at $\$ 7,000$. While many states do have UI tax bases above the federal base, most are not much higher than the federal base, with none anywhere close to the OASDI base. As a result of this anomaly, only those with very low earnings pay the tax on their entire wages. Additionally, workers who have already paid taxes up to the taxable wage base with one employer in a calendar year must pay again if they change jobs or moonlight. Thus, those who lose a job or work additional hours at a second job are also more likely to pay taxes on a higher fraction of earnings.

We examine the distributional consequences of the UI payroll tax using representative individual microdata. We first calculate UI taxes paid by income decile, incorporating the effects of multiple job holding and job turnover. The distribution of UI taxes is also compared with the distribution of UI benefits and benefits net of taxes. UI benefit receipt is unlikely to be evenly distributed across the income distribution, since both layoff rates and benefit take up differ across individuals. This comparison makes clear that when used exclusively to pay for unemployment benefits, the regressive nature of the UI payroll tax is outweighed by the progressiveness of the benefit schedule. Thus, net benefit rates decline across deciles.

We then consider two applications. First, since the regressivity of the UI payroll tax stems mainly from the very low tax base, we consider the distributional consequences of increasing the base to the level of the OASDI base, as it was originally. We simulate this 
increase in combination with a cut in tax rates that is revenue neutral for the program. This distribution is much less regressive than that under the current system. Second, we consider using the UI system to fund family leave benefits, as was allowed by a 1999 executive order, but would be rescinded under a pending Department of Labor rule. We simulate eligibility for new parents in our data set, based on the UI monetary eligibility rules in effect at that time. We report eligibility because it can be measured well, while actual receipt rates will differ from eligibility due to takeup rates and the duration of a leave that may differ across groups. In addition, our focus is mostly on the funding source for paid leave, rather than the details of a paid leave program. Thus, we also compare the distributional consequences of using the current UI payroll tax versus the main alternative funding source for a government sponsored paid leave program - the federal income tax.

The paper continues with a description of the data and methodology in Section II, while Section III discusses the basic results for the UI tax and benefit distributions. Section IV contains the applications of funding family leave and reforming the payroll tax, and Section V provides some concluding remarks.

\section{Data and Methodological Considerations}

Extensive data are required to accurately measure UI taxes paid, UI benefits received, and to simulate tax changes and potential eligibility for a UI based family leave benefit. To measure UI taxes paid we need employment over a calendar year on a job by job basis as UI taxes are paid (up to the tax base) on each job during a calendar year. To have a good measure of UI benefits, it is helpful to have a survey that focuses on measuring program receipt and dollars received on a timely basis without a long recall period. In addition, having multiple years 
of income information is helpful since income during years of UI receipt may not capture income in more typical years. To simulate eligibility for birth and adoption benefits, we need earnings by quarter during the first four of the five quarters prior to the quarter of birth. These quarterly earnings determine eligibility for UI and the amount of the weekly benefit in the vast majority of states.

These requirements led us to use data from the Survey of Income and Program Participation (SIPP) in our estimation and simulation. The SIPP is a series of nationally representative panel data sets, each made up of a number of waves. ${ }^{1}$ Each wave asks the respondent about income and program participation over the last 4 months. A typical panel lasts for 2.5 to 4 years and has a sample size of 14,000 to 36,700 households. $^{2}$ The 1993 panel, which began in February 1993 and continued through January 1996, is the latest that was fully available at the start of this project. Given the nature of data collection, we have a complete calendar year for the full sample only for 1993 and 1994. Thus, we look at the UI tax and benefit distribution for the more recent year. Our use of 1994 also gives a fairly representative view of the typical balance between benefits and taxes, as the ratio of aggregate taxes to benefits is close to its longrun average (see the Data Appendix for details). Current data would likely indicate a distribution of tax payments that is slightly more regressive than the distribution reported here. Because the federal tax base has not been increased and state tax bases have not kept up with inflation, those with low wages or incomes probably pay a larger share of taxes now than in 1994.

The SIPP is ideal for our purposes because it contains information on the receipt of UI benefits. However, as is common in surveys of program participation, benefit receipt appears to

\footnotetext{
${ }^{1}$ Additional details about the creation of the analysis sample can be found in the Data Appendix.

${ }^{2}$ For more information on SIPP, see http://www.sipp.census.gov/sipp/
} 
be underreported, so we proportionally scale up benefits by 38 percent to better match the National Income and Product Account figures. ${ }^{3}$ We estimate UI taxes paid based on individual earnings and the state and federal taxable wage bases and rates. Both the taxable wage base and the average employer tax rate as a percentage of the taxable wage base are available in Unemployment Insurance Financial Data, ET Handbook 394. The values for 1994 are shown in Table $1 .{ }^{4}$ Only 21 states have a tax base of at least $\$ 10,000$ and only four have one of at least $\$ 20,000$. Note that in that year the social security tax base was $\$ 60,600$, nearly two and one-half times the base in the highest state. For each job held in the calendar year, we calculate taxable earnings based on the state wage base, and using the average tax rate in the state we estimate state UI taxes paid. ${ }^{5}$ Based on the federal wage base and tax rate, federal UI taxes are also calculated.

In order to examine the distribution of UI tax burdens and benefits, we must divide the sample into deciles, a task that raises several methodological issues as there are several possible approaches. First, based on reported earnings and hours, we can calculate individual wage rates for workers and define individual wage deciles. ${ }^{6}$ Alternatively, we can calculate total income for workers and non-workers alike and define individual income deciles. In either case, the sample is limited to adults. Since the household is the sampling unit in the SIPP, we can also compute total household income and define household income deciles. ${ }^{7}$ Note that reported earnings will be lower than they would be in the absence of any tax, reflecting that the average UI tax rate can

\footnotetext{
${ }^{3}$ Bound et al. (2001), Mathiowetz et al. (2002) and Meyer and Sullivan (forthcoming) provide an extensive discussion of and cites to other work on underreporting of benefits for many social insurance and welfare programs. ${ }^{4}$ Additional information on the computation of the rates and bases for the grouped states are given in the Data Appendix.

${ }^{5}$ For public sector and nonprofit employees, taxes paid are set equal to benefits to reflect the likelihood the employer is not taxed, but rather reimburses the state UI fund. Less than 10 percent of benefits are paid to employees of reimbursable employers.

${ }^{6}$ If an individual has no reported earnings or hours in 1994, but earnings and hours are available for 1993, then a wage is calculated from the prior year's data.
} 
be passed through to the workers in the form of lower wages (e.g. Anderson and Meyer, 1997, 2000). In what follows, we present results using all three measures of resources - individual wages, individual income and household income, since they each have different strengths and weaknesses.

An advantage of focusing only on workers by using the wage measure to define deciles is that the UI program is designed to solely benefit individuals with an attachment to the labor force. Thus, looking across wage deciles for workers focuses directly on this target sample. However, since labor supply is not taken into account there may not be a linear relationship across workers between wages and income that would leave deciles unchanged. Thus, looking across individual income deciles may give a better picture of financial resources. At the same time, a fraction of this sample is likely to have no attachment to the labor force, and thus to play no role in the UI program. An alternate measure of overall material well-being, then, is household income. While some households may still contain no individuals with labor force attachment, the fraction of the sample with no stake in the UI program is likely much smaller than is the case for individuals. Grouping households by income does raise an additional issue, however, in that households with similar incomes, but of different sizes, will actually have different standards of living. One could simply use per capita income, but this method ignores economies of scale and the difference between children and adults. Thus, it is necessary to use an equivalence scale to account for these differences. In calculating deciles, then, we standardize household income by indexing it to a 2-adult, 2-child household. ${ }^{8}$

A final issue is that ideally we would like to divide the sample into deciles based on a measure of permanent income that abstracts from temporary wage and income shocks. By

\footnotetext{
${ }^{7}$ The components of income are described in more detail in the Data Appendix.

${ }^{8}$ See the Data Appendix for details of this standardization.
} 
definition, those receiving UI benefits have suffered an earnings shock. If we use wages or income in a given year to define the deciles, we would likely overstate the UI benefits received in that same year by the lowest deciles. That is, in addition to those whose permanent income places them in the lowest deciles, those suffering a temporary earnings shock (and thus receiving UI benefits) are also included. To reduce this problem, we assign individuals or households into deciles based on their 1993 wages or income when calculating the 1994 UI benefit receipt distribution.

\section{The UI Tax and Benefit Distributions}

By individual wage and income deciles, as well as standardized household income deciles we compute UI taxes paid, UI benefits received, and total income received by individuals (or households in the latter case) in each decile. From these decile totals we compute tax rates and benefit rates for each decile by dividing total UI taxes paid by total income received in the decile and total UI benefits by total income. We then compute the net UI benefit rate as total benefits received minus total taxes paid divided by total income. ${ }^{9}$ We also compute the share of total UI taxes paid and total UI benefits received by each decile. The results of each of these calculations, along with the wage or income values defining the deciles are presented in Table 2 .

Looking at the UI payroll tax rate, we see that as expected it is very regressive, especially for the workers for whom the program is intended. Focusing first on this top panel, the lowest earners making about $\$ 5$ an hour pay almost 3 percent of their income, while high earners making over \$20 an hour pay less than half a percent of theirs. The disparity is not just at the extremes. The UI tax rate for the lowest paid is over twice that of those earning about $\$ 11$ an hour (the sixth decile), which is itself over three times that of the highest earners. While still 
regressive, the contrast is not as stark in the lower two panels. By widening the focus to all adults and household income we include those who pay no payroll taxes as they are not in the labor force. Nonetheless, in the second panel we see that the lowest half - those with incomes less than about $\$ 15,000$ pay at a rate four times those in the top decile with incomes over about $\$ 44,000$. In the final panel, we see a more even distribution of rates across households.

Nonetheless, the top decile, with income close to $\$ 100,000$ or more pays at less than half the rate of households with incomes below about $\$ 50,000$.

Perhaps one reason the regressivity of this tax has not been considered a concern is both that the tax is small and that it funds a benefit that is capped at a relatively low dollar value. In most states, maximum weekly benefits are well below $\$ 350$, and in a few states are below $\$ 200$. Thus, while it is clear that the lowest wage deciles pay the highest fraction of income in UI taxes, this group also receives the highest fraction of income in benefits. In fact, only the lowest wage decile (those with wages less than $\$ 4.41$ an hour) receives non-negative net benefits. ${ }^{10}$ Turning to the individual income deciles, we see an especially high benefit rate for the lowest decile.

Finally, the benefit distribution across household income deciles in the bottom panel looks more similar to that in the top panel. Given the somewhat more equal tax rates across income deciles, though, the net benefit rates are positive (albeit small) across more deciles, but still remain negative for the majority of deciles. Recall that although we have taken steps to mitigate the problem, we still expect our results to overestimate the benefits received by the lowest decile of permanent income, as those suffering from temporary income shocks may still be overrepresented in this group.

\footnotetext{
${ }^{9}$ Alternatively, this can be computed as the UI benefit rate minus the UI tax rate.

${ }^{10}$ Note that this measure of net benefits reflects the number of dollars transferred through the UI program, but does not reflect the insurance value of UI.
} 
An alternative way to think about the UI tax and benefit distribution is to examine the share of total taxes paid and benefits received by decile. In the top panel, we see that the share of taxes is relatively equal, albeit slightly higher for the middle deciles and lowest for the bottom deciles. This result is not surprising, as we might expect that the lowest wage deciles will include workers who do not reach the taxable maximum, while the middle wage deciles may be most likely to include workers with multiple employers. In the lower two panels the distributions are less equal, but rise almost monotonically. The middle panel makes especially clear that the lowest income decile includes all of those individuals with no labor market attachment. This decile therefore pays less than one half a percent of total UI taxes.

Turning to the share of benefits, we see that the upper end of the distribution receives a larger share of total UI benefits than one might have thought given the benefit rate distribution. In the top panel, we see that the lowest 30 percent receive just 23 percent of the benefits, while the 30 percent in the upper-middle deciles (six to eight) earn 37 percent. Looking at the second panel, we see that the benefit distribution is even less equal, again because the lowest income deciles include individuals with no labor market attachment. Once more, though, it is deciles six to eight receiving the largest share. Here, this 30 percent with earnings between about $\$ 15,000$ and $\$ 32,000$ receive $46 \%$ of the benefits. Finally, in the bottom panel the distribution is quite equal, with no decile receiving more than about 12 percent or less than about 8 percent, and with the lowest 60 percent receiving just about 60 percent of benefits.

This bottom panel is most comparable to a small existing literature on the distribution of UI benefits by income group. Using data from 1966 that was adjusted to represent 1970 population, family income and asset values, Feldstein (1974) calculated that the lowest 60 percent of families received 59 percent of benefits in 1970. While this finding is very close to 
ours, using a different data set, but again for 1970, Feldstein (1977) later concluded that the lowest 60 percent of households received over 72 percent of benefits. Finally, using an updated and improved version of Feldstein's original data, Hutchens (1981) concluded that the 1970 benefit distribution was indeed more progressive than Feldstein originally thought based on those data. While the distribution is not presented by deciles, one can compute that the lowest 63 percent of families received 69 percent of benefits.

While overall it appears that the distribution across households has not changed dramatically over approximately 25 years, there is some indication that the top of the distribution now receives a slightly larger share of benefits than before. ${ }^{11}$ We find that the top 20 percent of households receive 18 percent of benefits. By contrast, Hutchens (1981) reported that the top quintile received about 10 percent of benefits, while Feldstein (1977) found that the top 18 percent received just 8 percent of benefits. Hutchens attributed the relatively high level of benefit receipt among the higher quintiles to an increased probability of labor force participation within the family. Between 1970 and 1994, the labor force participation rate of married women rose from 41 percent to 61 percent (U.S. Census Bureau, 2000). An increase in secondary earners within relatively high-income households could result in the observed increase in UI benefit receipt among such households. However, in each panel of Table 2, the top quintile receives close to $20 \%$ of benefits, so a comparison between household and individual income deciles does not help support the idea that an increase in secondary earners caused the increased share of benefit receipt by the top household deciles.

\footnotetext{
${ }^{11}$ Note that compared to 1970 , UI benefits are now taxable as income. All rates computed in Table 2 are pre-tax benefits relative to pre-tax income, versus non-taxed benefits relative to pre-tax income in the past studies.
} 


\section{Applications}

\section{A. Simulating a Revenue Neutral Increase in the Tax Base}

As has been shown, the UI payroll tax distribution is very regressive. Due to the very low taxable wage base, most workers pay similar amounts in UI taxes, meaning that those with lower incomes pay at a much higher rate than those further up the income distribution. Recall that when the UI and OASDI programs were begun in 1935, however, they were financed by payroll taxes on identical wage bases. If the UI taxable wage base were to be increased to again be level with the OASDI wage base, UI tax rates could be reduced accordingly. This revenueneutral change would then likely have important effects on the distribution of the UI payroll tax.

To simulate the effect of this revenue-neutral increase in the tax base, we first calculate total taxable wages by state under both the actual and the higher 1994 OASDI wage base of $\$ 60,600$. For each state, the true 1994 tax rate is multiplied by the ratio of actual taxable wages to projected taxable wages to obtain the revenue-neutral decrease in tax rates. The federal tax rate is reduced in the same manner. These revenue-neutral tax rates are also shown in Table 1.

Table 3 is then identical to Table 2, but with the imposition of this revenue-neutral change in the UI taxable wage base and tax rates. The effect on the tax rate distribution (and by extension the net benefit rate distribution) is quite noticeable, and is especially clear across wage deciles. The change results in each decile paying close to 1 percent of income in UI payroll taxes. Recall that under the current system those earning around $\$ 5$ per hour pay almost 3 percent, while those earning over $\$ 20$ pay just under one-half of one percent. Net benefits are now positive for the first six individual wage deciles before becoming slightly negative for the rest. While for these highest deciles net benefits are now somewhat more negative than was found using the actual wage base, they remain below 1 percent. 
Results are similar across income deciles, although the difference is perhaps less stark. Across all individual and household deciles, taxes are less than 1 percent of income, and are now slightly progressive with a slight dip only for the highest decile. UI taxes are just 0.5 percent of income for households earning less than about $\$ 15,000$ and rise slightly to 0.8 percent for households earning about $\$ 35,000$ to $\$ 98,000$. This pattern is almost the opposite of the current lower tax base, under which the lowest income deciles paid 1 percent in taxes, and the highest paid about 0.5 percent. Net benefits now are positive for all but the top 30 percent of individuals. Even for the top decile the negative benefit rate is just one half of a percent of income. While fully half of households continue to face a negative benefit rate, it again remains under one half of a percent of income.

Overall, then, it is clear that a revenue-neutral change in the taxable wage base would make the UI payroll tax less regressive across wage deciles and it would be slightly progressive across income deciles. For those with the lowest wages and incomes, the tax rate is cut at least in half, and sometimes by a third. At the same time, only those with the highest wages (more than about $\$ 15$ per hour) and incomes (more than about $\$ 32,000$ for individuals and $\$ 75,000$ for a 4-person household) see a substantial increase in rates. Even for these groups, the rate at worst approximately doubles, and it always remains below 1 percent of income.

\section{B. Simulating Providing Family Leave within the UI System}

Providing family leave within the UI system is an idea that has been raised from time to time. After an executive order was signed in 1999 allowing states to adopt laws creating such a benefit, 12 states considered such laws without any of them successfully implementing them (Atkinson, 2003). This executive order has since been rescinded, for now removing the possibility of using the UI program to provide family leave. However, commentators continue to 
advocate such a program (Atkinson, 2003). Were this policy (referred to as Birth and Adoption Unemployment Compensation, or BAA-UC) to be reinstated, the distributional impact would likely be very different from that of the regular UI program.

As seen earlier, while the UI payroll tax is quite regressive, the lowest wage individuals and lower income households benefit more from the UI program, leaving the higher deciles to face negative benefit rates. However, the incidence of job loss and subsequent UI benefit receipt is likely much more concentrated in the lower deciles than would be the receipt of BAA-UC benefits.

In order to simulate eligibility for BAA-UC benefits, we need at least 5 calendar quarters of data before the birth of the child in order to calculate base period earnings. Thus, we focus on births that take place in the year starting with the second quarter of 1994 and ending with the first quarter of 1995. This strategy implies using qualifying wages earned in base periods during 1993 and 1994, throughout which time a full sample is available. However, because we must simulate each state's eligibility and benefit formulas, we must exclude the small states that are not identified in the SIPP. ${ }^{12}$

Table 4 presents the fraction of new parents that would be monetarily eligible for BAAUC upon the birth of their child, along with the share of potential weekly benefits, for each decile defined as in Table 2. Looking first at individual wage deciles, we can see that the lowest wage earners are the least likely to qualify for BAA. The probability of a new parent being eligible is fairly steady at around 90 percent for those earning above $\$ 6.60$ per hour. In most deciles, new fathers are more likely to be eligible than are new mothers, with this effect being most notable among the lowest paid. It should be noted, however, that the sample sizes for new fathers are small in the lower deciles, and increasing (because we use the same decile cutoffs for 
both genders), while those for new mothers are relatively large to start and then decline across deciles. Thus it may be unwise to read too much into these differences across gender.

A similar pattern of eligibility is seen across individual income deciles in the middle panel. As was the case with regular UI benefits, the lack of labor force attachment among those with very low incomes leads to low levels of eligibility for BAA-UC. Thus, it is not until about the sixth decile, for those earning a bit over $\$ 15,000$ that the new parent eligibility rate stabilizes at around 90 percent. Again there are some small differences in eligibility between new mothers and fathers, although in the higher deciles it is the mothers who are more likely to be eligible, but the caveat about declining sample sizes for mothers should be kept in mind.

The final panel focuses on the household, looking at the eligibility rate of new mothers, new fathers and new parent households (i.e. at least one of the new parents is eligible) across standardized household income deciles. As with the individual-level distributions, the lowest income households are least likely to be eligible for BAA-UC benefits, with the eligibility rate stabilizing at around 90 percent for those with more than about $\$ 43,000$ in income (again at the sixth decile). The father in the household is uniformly more likely to be eligible than is the mother. Given the size of these differences and that the sample sizes are somewhat more uniform across household deciles, a real difference in male-female eligibility due to differences in labor force attachment is likely being displayed here.

The distribution of potential BAA-UC weekly benefits is very different from the distribution of actual regular UI benefits received. Here, the lowest deciles (whether individual wage, individual income or standardized household income) receive the lowest share, often only around 5 percent or less, while the highest deciles receive 15 to 20 percent of BAA-UC benefits.

\footnotetext{
${ }^{12}$ Details of the process of determining eligibility and benefit levels can be found in the Data Appendix.
} 
A caveat to our calculations is that we do not have a basis for determining how takeup rates for BAA-UC or the duration of receipt will differ across groups. Thus, we examine the distribution of those likely eligible for such benefits. To the extent that there are differences across deciles in either take up or duration of benefits, the distribution of total benefits received would be affected. Unfortunately it is very difficult to speculate about how these behaviors are likely to vary by wage or income level. It is possible, though, to roughly describe their effect on the benefit distribution. For example, if one believes higher wage/income parents are less likely to take up benefits (perhaps due to employer-provided paid leave that is not displaced by the BAA-UC program) and/or more likely to have shorter durations, then the total benefit distribution would be attenuated and thus more equal. Alternatively, if one believes that lower wage/income parents are less likely to take up benefits and/or more likely to have shorter durations (perhaps due to low benefit levels and the necessity to return more quickly to full pay), then the total benefit distribution would be even more unequal than that of the potential weekly benefit. We also assume that individuals do not time their work or child-bearing to alter their BAA-UC eligibility.

Given that the UI payroll tax is a very regressive funding mechanism and that parental leave benefits are disproportionately received by high income households, it is reasonable to consider an alternative to the UI tax as a funding mechanism. The most obvious funding alternative is general revenues which are largely generated by the income tax. To compare funding parental leave through the UI payroll tax to funding it through general revenues, we simulate federal income taxes for our sample. While the SIPP does have tax information for 1994 in the Wave 8 Topical Module, the tax bill is reported in $\$ 500$ increments and is capped at $\$ 14,000$. Thus, we instead use the National Bureau of Economic Research's TAXSIM program 
to estimate federal income taxes. ${ }^{13}$ The simulation will be an approximation since filing status and deductions are not available. Thus we simply use the SIPP data on income components, marital status and dependents, and then assume the standard deduction for everyone. In general, this approximation should be fairly accurate for all deciles except for those at the very top that are not our focus. ${ }^{14}$

Table 5 repeats the UI tax rates and shares from Table 2, comparing them to the simulated income tax rates and shares. To place the results in context, income shares are also shown. Starting with the top panel, we can see that for adult workers, the distributional consequences of the UI tax and the federal income tax are very different. While the income tax is much larger than the UI tax, it is generally very progressive. The tax rate at the top decile, for those earning over $\$ 20$ an hour, is just over twice that at the bottom for those earning less than $\$ 4.41$ an hour. A similar pattern is seen in the middle panel.

Since the federal income tax is not really based on individual earnings or income, the bottom panel which looks at household income deciles is likely to provide the best comparison. The income tax appears even more progressive when examined at this level. In fact, due to credits, in particular the Earned Income Tax Credit, net tax payments are negative for the first two income deciles (up to about $\$ 21,000$ ), quickly rising to about 9 percent in the seventh decile (income of around $\$ 55,000$ ) and then more than doubling to over 18 percent in the final decile (income around $\$ 100,000$ or more).

Comparing the share of UI taxes and income taxes to the share of income is an enlightening exercise. All but the top 20 percent of households pay a larger share of total UI

\footnotetext{
${ }^{13}$ A public-use version of the program can be accessed on-line at http://www.nber.org/ taxsim/taxsimcalc/index.html

${ }^{14}$ A comparison of our calculations with IRS figures shows that while we underestimate total taxes paid, the distribution of rates is quite close until the highest income households.
} 
taxes than is their share of total income. By contrast, this same top 20 percent are the only households to pay a much larger share in income taxes than is their share of income. Thus, Table 5 clearly illustrates both the progressive nature of the income tax and the regressive nature of the UI payroll tax.

\section{Conclusions}

It is generally recognized that payroll taxes in the United States are regressive relative to the income tax. However, the focus is generally on the Social Security system, with very little attention paid to the Unemployment Insurance payroll tax. ${ }^{15}$ We provide just such an analysis of the UI system, based on representative individual-level microdata. We calculate taxes paid by individual wage and individual and household income deciles, incorporating the effects of multiple job holding and turnover. This distribution of taxes is contrasted with the distribution of regular UI benefits, and compared to the burdens imposed by the federal income tax. We conclude that the UI payroll tax is indeed very regressive, both across households and individuals. Not surprisingly, the burden is especially high for low-wage workers, relative to those with higher wages. Workers in the lowest deciles pay almost 3 percent of their income in UI payroll taxes, while those in the highest deciles pay only around 0.5 percent. While less extreme at the household level, since the lowest deciles pay about 1 percent of income in this case, the highest deciles still pay only about 0.5 percent.

Within the context of the regular UI program, the regressivity of the payroll tax is offset by the progressive nature of benefits, leaving the net benefit distribution progressive. Nonetheless, while the benefit rate declines with individual wage, individual income and 
household income deciles, the top deciles still receive a nontrivial fraction of total benefits. For example, the top two deciles of the individual wage, individual income and household income distributions receive about 18 percent of total benefits.

The severely regressive nature of the UI tax system stems mainly from the very low taxable wage base. Given that this wage base was originally identical to that for OASDI, we simulate an increase in the taxable wage base to the OASDI level accompanied by a revenueneutral decrease in tax rates. Under such a system, the fraction of income paid in taxes still declines across individual wage deciles, but only from 1.3 percent to 0.9 percent. Across income deciles there is a slight progressivity, with taxes rising from about 0.5 percent to 0.8 percent at both the individual and household level. The share of total UI taxes paid becomes fairly equal, and net benefits become positive across more deciles.

Finally, we examine the effect of providing family leave within the UI system. Based on our simulation of eligibility for BAA-UC benefits among new parents, it appears that the share of such benefits going to relatively high-income groups is likely to be much larger than is the case for regular UI benefits. In our simulation, the top two deciles of the individual wage distribution would be eligible for about 34 percent of weekly BAA-UC benefits, while for the household income distribution this share is about 30 percent. Thus, while the share of regular UI benefits received by each decile is fairly similar to the share of UI taxes paid, this is not likely to be true for BAA-UC benefits.

\footnotetext{
${ }^{15}$ There is a substantial literature looking at the distribution of other payroll taxes by income group. For example, Mitrusi and Poterba (2000) report that payroll tax liabilities now exceed income tax liabilities for nearly two-thirds of families.
} 


\section{Data Appendix}

We use the Survey of Income and Program Participation (SIPP) to estimate the distribution effects of UI taxes and benefits. The SIPP is a series of nationally representative panel data sets, each made up of a number of waves. A typical panel lasts for 2.5 to 4 years and has a sample size of 14,000 to 36,700 households. ${ }^{1}$ The 1993 panel, which began in February 1993 and continued through January 1996, is the latest that was fully publicly available at the start of this project. A quarter of survey households are interviewed each month. Those first interviewed in February 1993, were last interviewed in October 1995. Each wave asks the respondent about income and program participation over the previous 4 months. For that group, then, we have information covering October 1992 through September 1995. Thus, we have a complete calendar year for the full sample only for 1993 and 1994, despite each sample member being interviewed for about 36 months. Thus, we look at the UI tax and benefit distribution for 1994, the most recent year available.

In every month of the panel, information is collected on each of up to 2 jobs. Thus, except for those rare occasions where 3 or more jobs are held in one month, we can calculate accurate annual earnings separately for each job held over the year. For each job held in the calendar year, we calculate taxable earnings based on the state wage base, and using the average tax rate in the state we estimate state UI taxes paid. ${ }^{2}$ Based on the federal wage base and tax rate, federal UI taxes are also calculated. A small complication in computing state UI taxes paid is that a few small states are not identified in the SIPP. Maine and Vermont are grouped together, as are Iowa, North Dakota and South Dakota, and Alaska, Idaho, Montana and

\footnotetext{
${ }^{1}$ For more information on SIPP, see http://www.sipp.census.gov/sipp/

${ }^{2}$ For public sector and nonprofit employees, taxes paid are set equal to benefits to reflect the likelihood the employer is not taxed, but rather reimburses the state UI fund. Less than 10 percent of benefits are paid to employees of reimbursable employers.
} 
Wyoming. For these states, we compute a population-weighted average tax base and tax rate for the states as a group, as shown in Table 1. This weighted average is then applied to all individual observations in the group. In the tax base increase simulations, the weighted tax rate is adjusted and applied to these groups of small states. For each month in the panel, information on program participation, including UI benefits received, is also collected, allowing us to compute total annual benefits received. We use the 1994 annual person weights to obtain totals that are comparable to the population.

To gauge the accuracy of our calculations, we compare total computed taxes and total computed benefits to published amounts. As is common in surveys of program participation, benefit receipt appears to be underreported. In the adult workers sample, for example, we obtain a total benefit figure of $\$ 16.9$ billion. By contrast, the National Income and Product Accounts (NIPA) imply that $\$ 23.8$ billion were received, although Roemer (2000) notes that adjustments for the sampling universe imply a SIPP benchmark of $\$ 23.3$ billion. ${ }^{3}$ We thus proportionally scale up benefits by 38 percent to better match the published figures, resulting in a total weighted benefit amount of $\$ 23.3$ billion. Our calculated total tax amounts match published figures quite closely. According to Unemployment Insurance Financial Data, ET Handbook 394, taxable employers collected $\$ 21.8$ billion in state UI taxes, while reimbursable employers paid $\$ 1.1$ billion in benefits (and hence reimbursed the state that amount). Our weighted totals from the SIPP (again from the adult workers) are $\$ 20.7$ billion in state taxes and $\$ 1.7$ billion in reimbursed benefits. We also calculate $\$ 5.2$ billion in federal taxes, for a total of $\$ 27.6$ billion in tax collections. Given that the state tax computations seem in-line with the actual collected amounts, and given the similar methodology, it may be reasonable to assume that the federal

\footnotetext{
${ }^{3}$ Note that Roemer also computes $\$ 19.6$ billion in UI benefits in SIPP in 1994, but uses a 3-wave aggregate weighting procedure rather than using the annual person weights that we use.
} 
amounts are also in line with reality. While we do not have exact figures for 1994, the average annual amount of federal UI tax receipts in the 20 -year period from 1981 to 2000 was about $\$ 5.2$ billion. $^{4}$

It is important to note that in an average year, we generally expect taxes collected to be greater than benefits received, due to administrative costs. For example, the federal portion of the tax funds all of the administrative costs for the UI program, as well as funding some employment services. Additional federal funds are placed in the Extended Unemployment Compensation Account (out of which the federal portion of extended benefits are paid) and the Employment Security Administration Account (which provides grants to states for UI and ES). Additionally, in any given year, state tax collections may outstrip benefits paid, with the excess being placed in a trust fund. In years of high unemployment, though, benefits may be paid out of the trust fund or from federal grants. Our chosen year of 1994 appears to be relatively typical, with state tax collections and total benefits being similar. Additionally, the 1994 NIPA benefit numbers are below those of the recession years of 1991-1993 (during which total benefits peaked at $\$ 38.9$ billion in 1992) and above those of the expansion years of 1995-2000 (during which total benefits averaged around $\$ 20$ billion). The most recent recession, however, has resulted in benefit totals much higher than had been seen in the past, with benefits totaling $\$ 62.9$ billion in 2002.5

Grouping households by income raises an additional issue, in that households with similar incomes, but of different sizes, will actually have different standards of living. One could simply use per capita income, but this method ignores economies of scale and the difference between children and adults. Thus, it is necessary to use an equivalence scale to account for

\footnotetext{
${ }_{5}^{4}$ See http://workforcesecurity.doleta.gov/dmstree/uipl/uipl98/uipl_2498c4a3.htm for details.

${ }^{5}$ See Table 2.1 at http://www.bea.doc.gov/bea/dn/nipaweb/NIPATableIndex.htm for the NIPA time series.
} 
these differences. Recently, the Panel on Poverty and Family Assistance appointed by the National Research Council's Committee on National Statistics has recommended a scale of the following form:

$$
\text { scale value }=(A+\mathrm{P} K)^{\mathrm{F}} \text {, }
$$

where $A$ is the number of adults in the household and $K$ is the number of children. ${ }^{6}$ Here, the parameter P should be between 0 and 1 , in recognition of the fact that children's needs are lower than adult needs. Thus, each child is treated as just a fraction of an adult. The panel recommends a value of 0.70 . The parameter $\mathrm{F}$ represents economies of scale for larger families, and thus should also be between 0 and 1 . The larger is the assumed savings per person from having a bigger household, the smaller is the value of $\mathrm{F}$ that should be chosen. The panel recommends a value of 0.65 to 0.75 . We follow the recommendations of the panel and thus set both $\mathrm{P}$ and $\mathrm{F}$ to 0.70. In calculating deciles, household income is standardized by indexing it to a 2-adult, 2-child household. ${ }^{7}$ Finally, we aggregate taxes paid and benefits received over the household and then use the 1994 annual person weight for the head of household to obtain nationally representative totals.

The information on income in the SIPP is very detailed. ${ }^{8}$ In addition to wage or salary income from up to two jobs and two businesses, data are collected on a full range of other income types. The other main categories are asset income (e.g. savings accounts, mutual funds, rental property), noncash income other than WIC and Food Stamps (e.g. rent subsidies, energy assistance), educational assistance (e.g. PELL, Stafford and Perkins grants, scholarships, student loans), program and miscellaneous income (e.g. social security, welfare, pensions, money from

\footnotetext{
${ }^{6}$ See Citro and Michael (1995) for details.

${ }^{7}$ Note that setting both $\mathrm{P}$ and $\mathrm{F}$ equal to 1 is the same as a simple per capita adjustment, which would then be multiplied by 4 to standardize to a 4-person household.
} 
friends or relatives). The income data are also available aggregated to the individual or household level. To define individual income deciles, we rely on the provided aggregate. For our household deciles, we also use the individual aggregates summed over all household members age 18 and over. This differs from the provided household aggregate, which includes all those age 15 and over.

Detailed income data are necessary for our estimation of federal income taxes. While the SIPP does have tax information for 1994 in the Wave 8 Topical Module, the tax bill is reported in $\$ 500$ increments and is capped at $\$ 14,000$. Thus, we instead use the National Bureau of Economic Research's TAXSIM program to estimate federal income taxes. ${ }^{9}$

The TAXSIM program uses the following variables: wage and salary earnings, dividends, property income, taxable pensions, Social Security, UI benefits. Based on the detailed individual income data, we are able to compute the total amounts for each of these categories for each individual. We then sum over all individuals age 18 and over in the household. Using these SIPP data on income components, as well as marital status and number of dependents, we then assume the standard deduction for everyone. In general, this approximation should be fairly accurate for all deciles except for those at the very top that are not our focus.

A comparison of the estimates obtained from TAXSIM in this manner with published IRS figures from 1994 indicates that we underestimate total taxes paid. However, the distribution across income deciles is quite close until the very highest income households. Given that higher income households are the most likely to itemize, it is not surprising that we have

\footnotetext{
${ }^{8}$ See Table 3-1 in the SIPP Users' Guide at http://www.sipp.census.gov/sipp/usrguide/sipp2001.pdf for a detailed listing of income components collected by the SIPP. We discuss only broad categories here.

${ }^{9}$ A public-use version of the program can be accessed on-line at http://www.nber.org/ $\operatorname{taxsim} / \operatorname{tax} s i m-$ calc/index.html
} 
more trouble estimating true tax amounts for this group. Nonetheless, our estimated shares of total taxes seem fairly similar across deciles to the IRS data.

A final computation we must make is an estimate of whether a new parent would be monetarily eligible to receive benefits if a BAA-UC program were in place. Based on the birthdates for everyone in the household, we can determine the quarter in which an adult became a new parent. Using the SIPP monthly earnings data we calculate an annual earning measure that is earnings in the first four of the five quarters prior to the birth, corresponding to the base period used for determining UI eligibility. Similarly, we determine which of these four quarters had the highest earnings. These base period earnings (BPE) and high quarter wages (HQW) are the main inputs to the eligibility and benefit schedules. In most states, a worker is eligible if BPE are greater than a certain level and are above a multiple (such as 1.5) of HQW. Similarly, benefits tend to be a fraction of HQW (such as $1 / 25^{\text {th }}$ ), subject to a maximum. Thus, based on the eligibility and benefit schedules in place at the time, we calculate the weekly benefit (if any) that each new parent would be eligible for under a BAA-UC program. ${ }^{10}$

\footnotetext{
${ }^{10}$ We thank Jonathan Gruber for providing us with his Stata code for implementing the state UI legislation.
} 


\section{References}

Anderson, Patricia M. and Bruce Meyer, "The Effects of Firm Specific Taxes and Government Mandates with an Application to the U.S. Unemployment Insurance Program," Journal of Public Economics, 65, (August 1997a): 119-145.

Anderson, Patricia M. and Bruce Meyer, "Unemployment Insurance Takeup Rates and the AfterTax Value of Benefits," Quarterly Journal of Economics, 112, (August 1997b): 913 937.

Atkinson, Robert D., "Putting Parenting First: Why it's Time for Universal Paid Leave," Progressive Policy Institute Policy Report, March 2003.

Bound, John, Charles Brown, and Nancy Mathiowetz, "Measurement Error in Survey Data.” In Handbook of Econometrics, Volume 5, eds. James J. Heckman and Edward Leamer, 3705-3843. Amsterdam: Elsevier, 2001.

Citro, Constance F. and Robert T. Michael, eds., Measuring Poverty: A New Approach, Washington, DC: National Academy Press, 1995. Available on-line at http://www.census.gov/hhes/poverty/povmeas/toc.html

Feldstein, Martin S., "Unemployment Compensation: Adverse Incentives and Distributional Anomalies," National Tax Journal 30, (June 1974): 219-221.

Feldstein, Martin S., "New Evidence on the Distribution of Unemployment Insurance Benefits," National Tax Journal 27, (June 1977): 231-244.

Hutchens, Robert, "Distributional Equity in the Unemployment Insurance System," Industrial and Labor Relations Review, 34, (April 1981): 377-385.

Mathiowetz, Nancy A., Charlie Brown and John Bound, "Measurement Error in Survey of the Low-income Population.” In Studies of Welfare Populations: Data Collection and Research Issues, eds. Michele Ver Ploeg, Robert A. Moffitt, and Constance F. Citro, 157194. Washington, DC: National Academy Press, 2002.

Meyer, Bruce D. and James X. Sullivan, "Measuring the Well-Being of the Poor Using Income and Consumption." Journal of Human Resources, forthcoming.

Mitrusi, Andrew and James Poterba, "The Distribution of Payroll and Income Tax Burdens 1979-99," National Tax Journal, 53, (2000): 765-794.

Roemer, Marc, "Assessing the Quality of the March Current Population Survey and the Survey of Income and Program Participation Income Estimates, 1990 - 1996," U.S. Census Bureau, June 16, 2000. 
United States Bureau of the Census, Statistical Abstract of the United States 2000. Available online at: http://www.census.gov/prod/www/statistical-abstract-us.html

United States Department of Labor, Employment and Training Administration, Unemployment Insurance Financial Data, ET Handbook 394. Available on-line at: http://www.workforcesecurity.doleta.gov/unemploy/content/HDBK394_99/home.htm

United States Department of Labor, Office of Workforce Security, "Labor Department's Economic Analysis of the Birth and Adoption Unemployment Compensation Plan," in Bureau of National Affairs - Daily Labor Report, June 13, 2000. 
Table 1: 1994 State Tax Rates and Bases

\begin{tabular}{|c|c|c|c|c|c|c|c|}
\hline State & $\begin{array}{c}1994 \\
\text { Average } \\
\text { Tax } \\
\text { Rate }\end{array}$ & $\begin{array}{c}\text { Revenue- } \\
\text { Neutral } \\
\text { Tax } \\
\text { Rate }\end{array}$ & $\begin{array}{c}1994 \\
\text { Tax } \\
\text { Base }\end{array}$ & State & $\begin{array}{c}1994 \\
\text { Average } \\
\text { Tax Rate }\end{array}$ & $\begin{array}{c}\text { Revenue- } \\
\text { Neutral } \\
\text { Tax Rate }\end{array}$ & $\begin{array}{c}1994 \\
\text { Tax } \\
\text { Base }\end{array}$ \\
\hline Alabama & 0.97 & $\mathrm{n} / \mathrm{a}$ & $\$ 8,000$ & New Mexico & 1.60 & 1.00 & $\$ 13,100$ \\
\hline Alaska & 2.55 & 0.46 & $\$ 23,800$ & New York & 4.68 & 1.49 & $\$ 7,000$ \\
\hline Arizona & 1.82 & 0.73 & $\$ 7,000$ & North Carolina & 0.65 & 0.41 & $\$ 13,200$ \\
\hline Arkansas & 2.12 & 1.25 & $\$ 9,000$ & North Dakota & 1.20 & $\mathrm{n} / \mathrm{a}$ & $\$ 13,000$ \\
\hline California & 3.55 & 1.14 & $\$ 7,000$ & Ohio & 2.77 & 1.08 & $\$ 8,750$ \\
\hline Colorado & 1.32 & 0.66 & $\$ 10,000$ & Oklahoma & 1.14 & 0.59 & $\$ 10,700$ \\
\hline Connecticut & 4.25 & 1.59 & $\$ 9,000$ & Oregon & 1.54 & 1.05 & $\$ 19,000$ \\
\hline Delaware & 2.64 & 1.08 & $\$ 8,500$ & Pennsylvania & 5.46 & 2.06 & $\$ 8,000$ \\
\hline District of Columbia & 3.61 & 1.76 & $\$ 9,500$ & Puerto Rico & 3.13 & $\mathrm{n} / \mathrm{a}$ & $\$ 7,000$ \\
\hline Florida & 1.92 & 0.74 & $\$ 7,000$ & Rhode Island & 3.65 & 2.34 & $\$ 16,400$ \\
\hline Georgia & 1.58 & 0.68 & $\$ 8,500$ & South Carolina & 1.88 & 0.69 & $\$ 7,000$ \\
\hline Hawaii & 1.06 & 0.94 & $\$ 25,000$ & South Dakota & 0.54 & $\mathrm{n} / \mathrm{a}$ & $\$ 7,000$ \\
\hline Idaho & 1.40 & $\mathrm{n} / \mathrm{a}$ & $\$ 20,400$ & Tennessee & 1.81 & 0.75 & $\$ 7,000$ \\
\hline Illinois & 3.43 & 1.32 & $\$ 9,000$ & Texas & 1.73 & 0.73 & $\$ 9,000$ \\
\hline Indiana & 1.37 & 0.49 & $\$ 7,000$ & Utah & 1.02 & 0.66 & $\$ 16,200$ \\
\hline Iowa & 1.29 & $\mathrm{n} / \mathrm{a}$ & $\$ 13,900$ & Vermont & 2.96 & $\mathrm{n} / \mathrm{a}$ & $\$ 8,000$ \\
\hline Kansas & 1.73 & 0.72 & $\$ 8,000$ & Virgin Islands & 1.46 & $\mathrm{n} / \mathrm{a}$ & $\$ 22,500$ \\
\hline Kentucky & 2.13 & 0.85 & $\$ 8,000$ & Virginia & 1.42 & 0.50 & $\$ 8,000$ \\
\hline Louisiana & 1.86 & 0.88 & $\$ 8,500$ & Washington & 1.96 & 1.38 & $\$ 19,900$ \\
\hline Maine & 4.22 & $\mathrm{n} / \mathrm{a}$ & $\$ 7,000$ & West Virginia & 3.05 & 1.49 & $\$ 8,000$ \\
\hline Maryland & 3.55 & 1.19 & $\$ 8,500$ & Wisconsin & 2.18 & 1.05 & $\$ 10,500$ \\
\hline Massachusetts & 3.95 & 1.65 & $\$ 10,800$ & Wyoming & 1.55 & $\mathrm{n} / \mathrm{a}$ & $\$ 11,400$ \\
\hline Michigan & 4.46 & 1.71 & $\$ 9,500$ & Grouped States: & & & \\
\hline Minnesota & 1.91 & 1.13 & $\$ 15,100$ & Maine \& Vermont & 3.82 & 1.52 & $\$ 7,319$ \\
\hline Mississippi & 2.20 & 0.95 & $\$ 7,000$ & Iowa, North Dakota, & & & \\
\hline Missouri & 2.67 & 1.13 & $\$ 8,500$ & \& South Dakota & 1.15 & 0.65 & $\$ 12,573$ \\
\hline Montana & 1.36 & $\mathrm{n} / \mathrm{a}$ & $\$ 15,100$ & Alaska, Montana, & & & \\
\hline Nebraska & 0.90 & 0.35 & $\$ 7,000$ & Idaho \& Wyoming & 1.64 & 1.17 & $\$ 18,194$ \\
\hline Nevada & 1.54 & 1.01 & $\$ 15,900$ & & & & \\
\hline New Hampshire & 2.18 & 0.82 & $\$ 8,000$ & Federal & 0.80 & 0.29 & $\$ 7,000$ \\
\hline New Jersey & 1.76 & 1.02 & $\$ 17,200$ & & & & \\
\hline
\end{tabular}

Notes: Revenue-neutral rate is based on the authors' calculations for a revenue-neutral increase in the tax base to the 1994 OASI tax base of $\$ 60,600$.

Source: US Department of Labor, Unemployment Insurance Financial Data, ET Handbook 394. 
Table 2: 1994 UI Tax, Benefit and Net Benefit Rates and UI Tax and Benefit Shares

\begin{tabular}{|c|c|c|c|c|c|c|}
\hline \multicolumn{2}{|l|}{ Individual } & \multicolumn{3}{|c|}{ Net } & \multicolumn{2}{|l|}{ Share of } \\
\hline Wage & UI Tax & UI Benefit & UI Benefit & Share of & UI & Decile \\
\hline Decile & Rate & Rate & Rate & UI Taxes & Benefits & Cutoff \\
\hline 1 & 0.028 & 0.030 & 0.002 & 0.040 & 0.051 & $\$ 4.41$ \\
\hline 2 & 0.027 & 0.026 & -0.001 & 0.077 & 0.088 & $\$ 5.50$ \\
\hline 3 & 0.022 & 0.018 & -0.004 & 0.093 & 0.091 & $\$ 6.60$ \\
\hline 4 & 0.018 & 0.015 & -0.003 & 0.103 & 0.105 & $\$ 7.83$ \\
\hline 5 & 0.017 & 0.012 & -0.004 & 0.121 & 0.108 & $\$ 9.23$ \\
\hline 6 & 0.013 & 0.011 & -0.001 & 0.112 & 0.120 & $\$ 10.83$ \\
\hline 7 & 0.011 & 0.009 & -0.002 & 0.120 & 0.121 & $\$ 12.83$ \\
\hline 8 & 0.008 & 0.008 & 0.000 & 0.110 & 0.127 & $\$ 15.64$ \\
\hline 9 & 0.006 & 0.005 & -0.001 & 0.110 & 0.106 & $\$ 20.08$ \\
\hline 10 & 0.004 & 0.003 & -0.002 & 0.113 & 0.085 & \\
\hline Individual & & & Net & & Share of & \\
\hline Income & UI Tax & UI Benefit & UI Benefit & Share of & UI & Decile \\
\hline Decile & Rate & Rate & Rate & UI Taxes & Benefits & Cutoff \\
\hline 1 & 0.012 & 0.068 & 0.056 & 0.004 & 0.024 & $\$ 2,000$ \\
\hline 2 & 0.011 & 0.013 & 0.002 & 0.030 & 0.041 & $\$ 5,451$ \\
\hline 3 & 0.012 & 0.011 & 0.000 & 0.055 & 0.061 & $\$ 8,316$ \\
\hline 4 & 0.013 & 0.011 & -0.002 & 0.088 & 0.086 & $\$ 11,612$ \\
\hline 5 & 0.013 & 0.012 & -0.002 & 0.122 & 0.124 & $\$ 15,260$ \\
\hline 6 & 0.011 & 0.011 & 0.000 & 0.131 & 0.158 & $\$ 19,418$ \\
\hline 7 & 0.010 & 0.009 & -0.001 & 0.146 & 0.156 & $\$ 24,387$ \\
\hline 8 & 0.007 & 0.007 & -0.001 & 0.144 & 0.146 & $\$ 31,655$ \\
\hline 9 & 0.006 & 0.004 & -0.001 & 0.141 & 0.128 & $\$ 43,730$ \\
\hline 10 & 0.003 & 0.001 & -0.002 & 0.140 & 0.075 & \\
\hline Household & & & Net & & Share of & \\
\hline Income & UI Tax & UI Benefit & UI Benefit & Share of & UI & Decile \\
\hline Decile & Rate & Rate & Rate & UI Taxes & Benefits & Cutoff \\
\hline 1 & 0.010 & 0.024 & 0.014 & 0.027 & 0.077 & $\$ 14,094$ \\
\hline 2 & 0.010 & 0.014 & 0.003 & 0.050 & 0.075 & $\$ 21,348$ \\
\hline 3 & 0.011 & 0.013 & 0.002 & 0.075 & 0.104 & $\$ 28,326$ \\
\hline 4 & 0.010 & 0.010 & -0.001 & 0.090 & 0.099 & $\$ 35,097$ \\
\hline 5 & 0.009 & 0.010 & 0.000 & 0.102 & 0.122 & $\$ 42,602$ \\
\hline 6 & 0.009 & 0.008 & -0.002 & 0.125 & 0.118 & $\$ 51,149$ \\
\hline 7 & 0.008 & 0.006 & -0.002 & 0.125 & 0.118 & $\$ 61,332$ \\
\hline 8 & 0.008 & 0.005 & -0.003 & 0.144 & 0.103 & $\$ 75,317$ \\
\hline 9 & 0.006 & 0.003 & -0.003 & 0.139 & 0.094 & $\$ 98,673$ \\
\hline 10 & 0.004 & 0.002 & -0.001 & 0.125 & 0.089 & \\
\hline
\end{tabular}

Notes: Household income deciles reflect income standardized for a 2 adult, 2 child household. Individual wage and income deciles are based on adult workers, and all adults, respectively. Benefit distributions are based on which decile 1993 income or earnings place the individual or household. All rates are calculated as total decile taxes or benefits divided by total decile income. All shares are calculated within sample and sum to one. All calculations are based on the Survey of Income and Program Participation, 1993 Panel. 
Table 3: UI Tax, Benefit and Net Benefit Rates and UI Tax and Benefit Shares Assuming Revenue Neutral Change in Wage Base and Tax Rates

\begin{tabular}{|c|c|c|c|c|c|c|}
\hline Individual & & & Net & & Share of & \\
\hline Wage & UI Tax & UI Benefit & UI Benefit & Share of & UI & Decile \\
\hline Decile & Rate & Rate & Rate & UI Taxes & Benefits & Cutoff \\
\hline 1 & 0.013 & 0.030 & 0.017 & 0.086 & 0.051 & $\$ 4.41$ \\
\hline 2 & 0.013 & 0.026 & 0.013 & 0.071 & 0.088 & $\$ 5.50$ \\
\hline 3 & 0.012 & 0.018 & 0.006 & 0.075 & 0.091 & $\$ 6.60$ \\
\hline 4 & 0.011 & 0.015 & 0.004 & 0.077 & 0.105 & $\$ 7.83$ \\
\hline 5 & 0.012 & 0.012 & 0.000 & 0.085 & 0.108 & $\$ 9.23$ \\
\hline 6 & 0.011 & 0.011 & 0.001 & 0.095 & 0.120 & $\$ 10.83$ \\
\hline 7 & 0.011 & 0.009 & -0.002 & 0.105 & 0.121 & $\$ 12.83$ \\
\hline 8 & 0.010 & 0.008 & -0.002 & 0.116 & 0.127 & $\$ 15.64$ \\
\hline 9 & 0.010 & 0.005 & -0.005 & 0.133 & 0.106 & $\$ 20.08$ \\
\hline 10 & 0.009 & 0.003 & -0.007 & 0.173 & 0.085 & \\
\hline Individual & & & Net & & Share of & \\
\hline Income & UI Tax & UI Benefit & UI Benefit & Share of & UI & Decile \\
\hline Decile & Rate & Rate & Rate & UI Taxes & Benefits & Cutoff \\
\hline 1 & 0.005 & 0.068 & 0.063 & 0.093 & 0.024 & $\$ 2,000$ \\
\hline 2 & 0.005 & 0.013 & 0.008 & 0.083 & 0.041 & $\$ 5,451$ \\
\hline 3 & 0.006 & 0.011 & 0.006 & 0.066 & 0.061 & $\$ 8,316$ \\
\hline 4 & 0.006 & 0.011 & 0.005 & 0.065 & 0.086 & $\$ 11,612$ \\
\hline 5 & 0.008 & 0.012 & 0.004 & 0.066 & 0.124 & $\$ 15,260$ \\
\hline 6 & 0.008 & 0.011 & 0.004 & 0.073 & 0.158 & $\$ 19,418$ \\
\hline 7 & 0.008 & 0.009 & 0.001 & 0.088 & 0.156 & $\$ 24,387$ \\
\hline 8 & 0.008 & 0.007 & -0.001 & 0.104 & 0.146 & $\$ 31,655$ \\
\hline 9 & 0.008 & 0.004 & -0.003 & 0.123 & 0.128 & $\$ 43,730$ \\
\hline 10 & 0.007 & 0.001 & -0.005 & 0.173 & 0.075 & \\
\hline Household & & & Net & & Share of & \\
\hline Income & UI Tax & UI Benefit & UI Benefit & Share of & UI & Decile \\
\hline Decile & Rate & Rate & Rate & UI Taxes & Benefits & Cutoff \\
\hline 1 & 0.005 & 0.029 & 0.024 & -0.048 & 0.077 & $\$ 14,094$ \\
\hline 2 & 0.006 & 0.021 & 0.015 & -0.020 & 0.075 & $\$ 21,348$ \\
\hline 3 & 0.007 & 0.014 & 0.007 & 0.018 & 0.104 & $\$ 28,326$ \\
\hline 4 & 0.007 & 0.011 & 0.004 & 0.040 & 0.099 & $\$ 35,097$ \\
\hline 5 & 0.008 & 0.009 & 0.001 & 0.060 & 0.122 & $\$ 42,602$ \\
\hline 6 & 0.008 & 0.008 & -0.001 & 0.073 & 0.118 & $\$ 51,149$ \\
\hline 7 & 0.008 & 0.005 & -0.003 & 0.088 & 0.118 & $\$ 61,332$ \\
\hline 8 & 0.008 & 0.005 & -0.003 & 0.107 & 0.103 & $\$ 75,317$ \\
\hline 9 & 0.008 & 0.003 & -0.004 & 0.135 & 0.094 & $\$ 98,673$ \\
\hline 10 & 0.006 & 0.001 & -0.005 & 0.185 & 0.089 & \\
\hline
\end{tabular}

Notes: Household income deciles reflect income standardized for a 2 adult, 2 child household. Individual wage and income deciles are based on adult workers, and all adults, respectively. Benefit distributions are based on which decile 1993 income or earnings place the individual or household. Individual income tax rates are taxes paid by the household relative to household income. All rates are calculated as total decile taxes or benefits divided by total decile income. All shares are calculated within sample and sum to one. All calculations are based on the Survey of Income and Program Participation, 1993 Panel. The revenue-neutral change assumes the 1994 OASI wage base of $\$ 60,600$ is accompanied by a decrease in tax rates (see Table 1 ) to be revenue neutral at the federal and state level. 
Table 4: Potential Distribution of BAA-UC Eligibility and Weekly Benefits

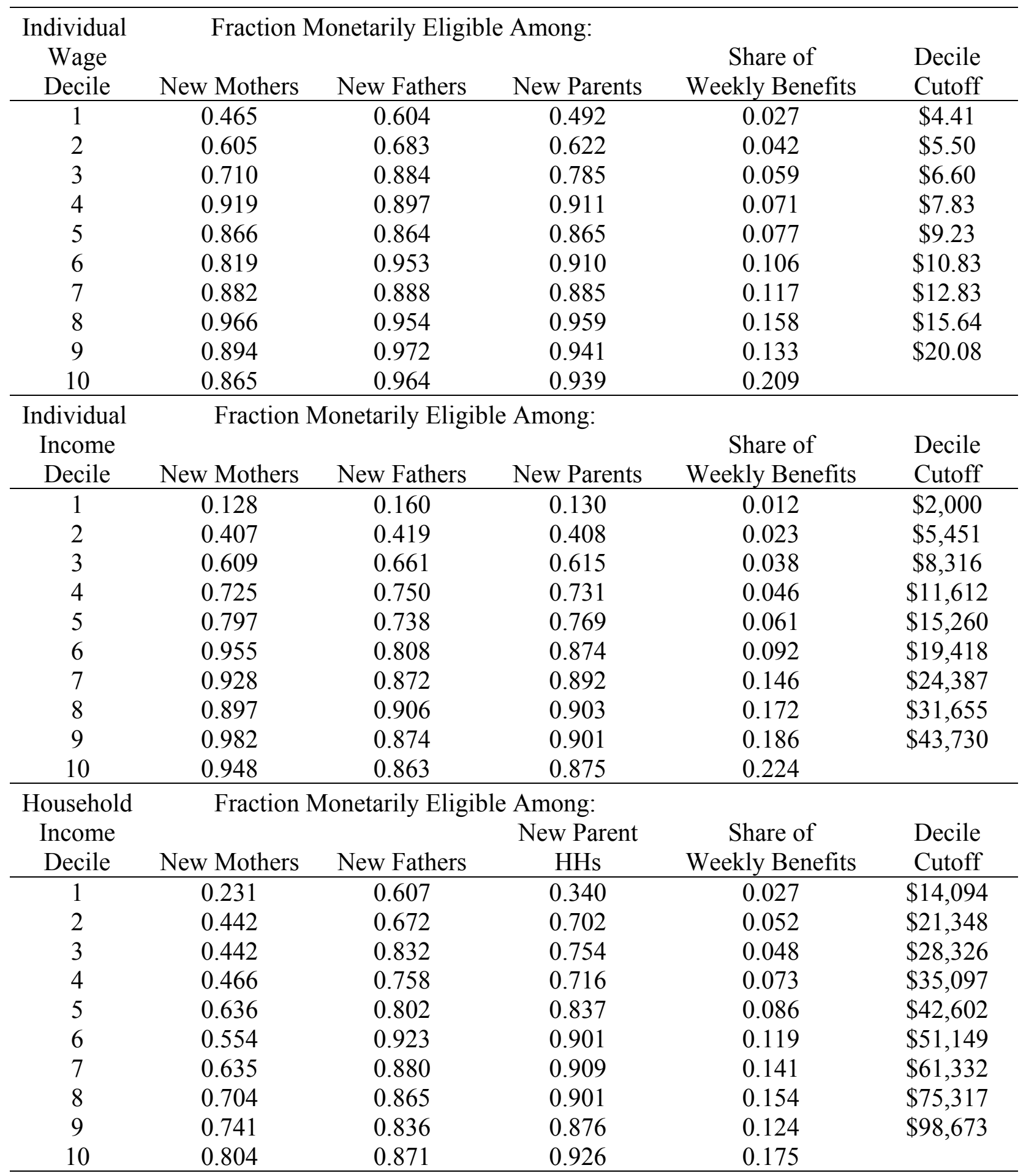

Notes: Household income deciles reflect income standardized for a 2 adult, 2 child household. Individual wage and income deciles are based on adult workers, and all adults, respectively. Eligibility is based on new births during 1994Q2 and 1995Q1; deciles based on 1994 income. All calculations are based on the Survey of Income and Program Participation, 1993 Panel. 
Table 5: 1994 UI Tax and Income Tax Rates and Income Tax and Income Shares

\begin{tabular}{|c|c|c|c|c|c|c|}
\hline $\begin{array}{c}\text { Individual } \\
\text { Wage }\end{array}$ & UI Tax & Income & Share of & $\begin{array}{l}\text { Share of } \\
\text { Income }\end{array}$ & Share of & Decile \\
\hline Decile & Rate & Tax Rate & UI Taxes & Taxes & Income & Cutoff \\
\hline 1 & 0.028 & 0.086 & 0.040 & 0.05 & 0.015 & $\$ 4.41$ \\
\hline 2 & 0.027 & 0.071 & 0.077 & 0.05 & 0.030 & $\$ 5.50$ \\
\hline 3 & 0.022 & 0.075 & 0.093 & 0.05 & 0.044 & $\$ 6.60$ \\
\hline 4 & 0.018 & 0.077 & 0.103 & 0.06 & 0.059 & $\$ 7.83$ \\
\hline 5 & 0.017 & 0.085 & 0.121 & 0.07 & 0.075 & $\$ 9.23$ \\
\hline 6 & 0.013 & 0.095 & 0.112 & 0.08 & 0.092 & $\$ 10.83$ \\
\hline 7 & 0.011 & 0.105 & 0.120 & 0.10 & 0.112 & $\$ 12.83$ \\
\hline 8 & 0.008 & 0.116 & 0.110 & 0.12 & 0.138 & $\$ 15.64$ \\
\hline 9 & 0.006 & 0.133 & 0.110 & 0.16 & 0.176 & $\$ 20.08$ \\
\hline 10 & 0.004 & 0.173 & 0.113 & 0.28 & 0.260 & \\
\hline Individual & & & & Share of & & \\
\hline Income & UI Tax & Income & Share of & Income & Share of & Decile \\
\hline Decile & Rate & Tax Rate & UI Taxes & Taxes & Income & Cutoff \\
\hline 1 & 0.012 & 0.093 & 0.004 & 0.07 & 0.002 & $\$ 2,000$ \\
\hline 2 & 0.011 & 0.083 & 0.030 & 0.06 & 0.019 & $\$ 5,451$ \\
\hline 3 & 0.012 & 0.066 & 0.055 & 0.04 & 0.034 & $\$ 8,316$ \\
\hline 4 & 0.013 & 0.065 & 0.088 & 0.04 & 0.049 & $\$ 11,612$ \\
\hline 5 & 0.013 & 0.066 & 0.122 & 0.05 & 0.066 & $\$ 15,260$ \\
\hline 6 & 0.011 & 0.073 & 0.131 & 0.06 & 0.086 & $\$ 19,418$ \\
\hline 7 & 0.010 & 0.088 & 0.146 & 0.08 & 0.108 & $\$ 24,387$ \\
\hline 8 & 0.007 & 0.104 & 0.144 & 0.11 & 0.138 & $\$ 31,655$ \\
\hline 9 & 0.006 & 0.123 & 0.141 & 0.16 & 0.184 & $\$ 43,730$ \\
\hline 10 & 0.003 & 0.173 & 0.140 & 0.33 & 0.314 & \\
\hline Household & & & & Share of & & \\
\hline Income & UI Tax & Income & Share of & Income & Share of & Decile \\
\hline Decile & Rate & Tax Rate & UI Taxes & Taxes & Income & Cutoff \\
\hline 1 & 0.010 & -0.048 & 0.027 & -0.009 & 0.020 & $\$ 14,094$ \\
\hline 2 & 0.010 & -0.020 & 0.050 & -0.007 & 0.035 & $\$ 21,348$ \\
\hline 3 & 0.011 & 0.018 & 0.075 & 0.009 & 0.050 & $\$ 28,326$ \\
\hline 4 & 0.010 & 0.040 & 0.090 & 0.025 & 0.065 & $\$ 35,097$ \\
\hline 5 & 0.009 & 0.060 & 0.102 & 0.045 & 0.079 & $\$ 42,602$ \\
\hline 6 & 0.009 & 0.073 & 0.125 & 0.067 & 0.096 & $\$ 51,149$ \\
\hline 7 & 0.008 & 0.088 & 0.125 & 0.095 & 0.113 & $\$ 61,332$ \\
\hline 8 & 0.008 & 0.107 & 0.144 & 0.139 & 0.137 & $\$ 75,317$ \\
\hline 9 & 0.006 & 0.135 & 0.139 & 0.217 & 0.169 & $\$ 98,673$ \\
\hline 10 & 0.004 & 0.185 & 0.125 & 0.419 & 0.238 & \\
\hline
\end{tabular}

Notes: Household income deciles reflect income standardized for a 2 adult, 2 child household. Individual wage and income deciles are based on adult workers, and all adults, respectively. Benefit distributions are based on which decile 1993 income or earnings place the individual or household. All rates are calculated as total decile taxes or benefits divided by total decile income. Individual income tax rates are taxes paid by the household relative to household income. All shares are calculated within sample and sum to one. All calculations are based on the Survey of Income and Program Participation, 1993 Panel. 